\title{
МЕТОДИКА ВИКЛАДАННЯ УКРАЇНСЬКОЇ МОВИ ЯК ІНОЗЕМНОЇ: ОСНОВНІ ТЕНДЕНЦЇ̈ СТАНОВЛЕННЯ ТЕРМІНОСИСТЕМИ ПРОТЯГОМ 90-Х РОКІВ ХХ СТОЛІТТЯ
}

\author{
ОКСАНА ТУРКЕВИЧ \\ Міжнародний інститут освіти, культури та зв'язків з діаспорою \\ Національного університету „Львівська політехніка”, Львів - Україна \\ METODYKA NAUCZANIA JĘZYKA UKRAIŃSKIEGO JAKO OBCEGO: \\ GŁÓWNE TENDENCJE FORMOWANIA SYSTEMU TERMINOLOGICZNEGO \\ W OKRESIE LAT 90. XX STULECIA \\ OKSANA TURKEWYCZ \\ Międzynarodowy Instytut Oświaty, Kultury i Związków z Diasporą \\ Narodowego Uniwersytetu „Politechnika Lwowska”, Lwów — Ukraina \\ STRESZCZENIE. W artykule przytoczone zostały główne aspekty rozwoju metodyki \\ nauczania języka ukraińskiego jako obcego w ciągu lat 90. XX wieku. Wyjaśniono ich wpływ \\ na kształtowanie się terminologii.
}

\section{METHODOLOGY OF TEACHING UKRAINIAN AS A FOREIGN LANGUAGE: MAIN TENDENCIES OF TERMINOLOGY FORMATION IN THE 90s OF THE XX ${ }^{\text {th }}$ CENTURY}

\section{OKSANA TURKEVYCH}

The International Institute of Education, Culture and Relations with the Diaspora of the Lviv Polytechnic National University

ABSTRACT. The article deals with the analysis of the methodology of teaching Ukrainian as a foreign language in the 90 s of the $\mathrm{XX}^{\text {th }}$ century.

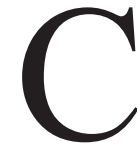

учасною тенденцією в розвитку наук є поширення інтеграційних процесів, що спричиняє виокремлення нових галузей. Поєднавши аспекти дидактики та лінгвістики, що необхідні в навчанні української мови іноземців, методика викладання української мови як іноземної (методика викладання УМІ) послідовно формує свою систему понять, що стає основою для утвердження іiї як окремої педагогічної науки, тобто між розвитком методики та іiі терміносистеми встановлюється взаємозалежність.

Методика викладання української мови як іноземної - це самостійна педагогічна наука, що досліджує теоретичні й практичні закономірності процесу викладання української мови як іноземної в різних умовах. Співвідносним із методикою викладання УМІ в українській науці є термін лінгводидактика. Трактування цієї спеціальної одиниці також $є$ різноаспектним, проте на основі порівняння різних тлумачень ${ }^{1}$ пропонуємо термін лінгводидактика вживати

${ }^{1}$ О. Туркев ич, Методика мови чи лінгводидактика?, [в:] „Українська термінологія і сучасність”, Київ 2009, вип. 8. 
на позначення інтегративної науки, що досліджує теорію навчання мови (рідної та іноземної).

Розвиток методики викладання УМІ активізувався після 1991 р., коли Україна здобула незалежність, що й стало причиною становлення третього етапу в розвитку української методичної терміносистеми (два перші періоди — це: a) 40-70-ті рр. й б) 80-ті pp. - 1991 р. ХХ ст.).

На першій конференції Украӥнська мова як іноземна: Проблеми методики викладання, що відбулася в Ялті 1993 р., О. Сербенська зазначила, що сучасна лінгводидактика, зокрема така іiї галузь, як навчання іноземців української мови, тільки за умови активного і творчого освоєння нових напрямів лінгвістики — теорії мовної діяльності, психолінгвістики, етнолінгвістики, лінгвістичної прагматики, комунікативної лінгвістики, пізнання міжмовних антропоцентричних тенденцій, якнайтісніше пов'язуючи лінгводидактичні та лінгвістичні проблеми, зможе успішно творити свою теорію, давати практичні поради, вписуватися в контекст сучасної дидактики ${ }^{2}$. Розвиток теорії в усіх зазначених аспектах спостерігаємо саме після визнання України незалежною державою. Методика викладання УМІ доповнюється авторськими програмами та науковими розвідками, що присвячені актуальним проблемам викладання української мови іноземним студентам. Книги, що вийшли друком в Україні після 1991 р., призначені для різних рівнів і профілів навчання, зорієнтовані на студентів - представників різних лінгвокультур. У 1995 р. надруковано Практичний курс украӥнської мови. Поглиблений етап вивчення Л. Паламар. Посібник „ставить за мету не лише закріпити, але й поглибити рівень знань з української мови для всіх, хто хоче вільно володіти нею як у процесі навчання, так і в інших ситуаціях мовного спілкування"з. Терміноодиниці цього навчального посібника номінують зміст навчання: ситуація мовного спілкування, типові мовні ситуації, граматичний матеріал, усне мовлення, писемне мовлення, словниковий запас; типи вправ на засвоєння мовних явищ, доповнюють конкретні базові методичні категорії: рівень знань з украӥнської мови, інтенсивний метод, поглиблене вивчення украӥнської мови як іноземної, практичний аспект навчання.

Одномовним підручником, який протягом тривалого часу застосовували під час навчання іноземців на підготовчих факультетах, є Вивчаємо українську, завдання якого „дати практичне володіння мовою”, а найбільша увага присвячена „виробленню у студентів основних мовних навичок і умінь на основі включеного у програму мовного матеріалу"4.

Ще однією книгою з УМI, надрукованою в 90-ті pp. ХX ст., є розширений курс Вивчаємо українську мову. Система уроків навчального видання послідовно і в дохідливій формі розкриває основи української граматики, сприяє формуванню базисного словникового запасу, навичок усного й писемного мовлення 5 .

2 О. Сербенська, Українська мова як об’єкт вивчення для іноземиів (соиіо-психолінгвістичний аспект), [в:] „Українська мова як іноземна: проблеми методики викладання”, збірник матеріал. Міжнар. наук. конф., Ялта вересень 1993, упоряд. І. Осташ, М. Гримич, Львів 1994, c. 14-20.

3 Л. М. Паламар, Практичний курс украӥнськой мови, поглиблений етап вивчення, навч. посібник, Київ 1995.

${ }^{4}$ Л. Г. Новицька, Т. М.Поліщук, Вивчаємо українську, Львів 1995, с. 3.

${ }^{5}$ I. В. Вихованець, С. А. Карпіловська, П. Ф. Клименко, Вивчаємо украӥнську мову. Розиирений курс, за ред. В. М. Русанівського, Київ 1996, с. 3. 
Єдиним посібником, який з'явився протягом 90-х, що призначений виключно для навчання іноземців граматики, є Украӥнська мова. Практичний курс граматики для студентів-іноземиів ${ }^{6}$.

Спеціальна система лексем цих посібників номінує різновиди засобів навчання: навчальний комплекс, практичний курс граматики, охоплює терміни категорії „зміст навчання”: словниковий запас, навички усного мовлення, навички писемного мовлення, комунікативна ситуація, лексичний мінімум на побутову / навчально-професійну / сочіально-культурну / суспільно-політичну теми .

Навчальні посібники Добридень! Посібник з украӥнської мови в малюнках і мовленнєвих моделях (I. Намакштанська) ${ }^{7}$ та Українська мова щзоня (М. Гримич, Н. Непийвода, В. Різун $)^{8} \epsilon$ ілюстрованими. У зв'язку зі специфікою посібників методична терміносистема доповнюється спеціальними одиницями, що позначають засоби зорової наочності: ілюстративний навчальний матеріал, ілюстрований словник, ілюстрований навчальний посібник з украӥнської мови для іноземиів.

Українська мова для іноземних студентів: початково-предметні курси це профільно орієнтований посібник, завданням якого на початковому етапі вивчення української мови є підготувати студентів до занять з математики, креслення, хімії, фізики, біології.

У зв'язку зі специфікою навчальне видання містить терміноодиниці, що позначають зміст навчання професійного спрямування: термінологічний мінімум, мінімум спеціальної лексики, мінімум синтаксичних структур, предметно-змістовні знання.

Наступний навчальний посібник - Украӥнська мова: Практичний курс для іноземиів ${ }^{10}$ — також належить до профільно орієнтованих. Книга призначена для іноземних слухачів підготовчих відділень і факультетів вищих медичних та фармацевтичних закладів освіти. Навчальне видання містить терміни, що значною мірою формують мікросистему власне методичних термінів: система уроків, контрольно-повторювальний урок, рівні володіння мовою, початковий рівень володіння мовою, елементарний рівень спілкування, мовні зразки, мовні ситуації, комунікативно-значущзі уміння, аудиторна робота та ін.

Розглянувши усі доступні тогочасні видання, призначені для навчання української мови іноземців, підсумуємо, що здобутки практичного напряму лінгводидактики протягом 90-х років XX ст. в Україні мають важливе значення не тільки для розвитку методичної термінології, а й для утвердження відповідної науки. У цьому періоді спостерігаємо значне якісне й кількісне збільшення методичних терміноодиниць, що спричинило формування різнотипних тематичних груп, у межах яких встановлюються ієрархічні відношення, що засвідчує розвиток методичної терміносистеми української мови. Протягом аналізованого періоду сформувалась основа власне методичних термінів: рівень воло-

${ }^{6}$ В. М. Вінницька, Н. П. Плющ, Украйнська мова. Практичний курс граматики для студентів-іноземиів, Київ 1997.

7 I. С. Намакштанська, Добридень! Посібник з украйнськой мови в малюнках і мовленнєвих моделях, Донецьк 1998.

${ }^{8}$ М. Гримич, Н. Непийвода, В. Різун, Украӥнська мова щзодня, Початковий рівень, навч. посібник, Київ 1998.

${ }^{9}$ Г. Он ков ич, Теоретичні основи використання засобів масової інформацї̈ у навчанні української мови студентів-нефілологів, автореф. дис. докт. пед. наук, Київ 1995.

${ }^{10}$ Х. Ш. Бахтіярова, С. С. Лукашевич, I. З. Майданюк, М. П. Сегень, С. В. Пєтухов, Украӥнська мова. Практичний курс для іноземиів, посібник для слухачів підготовчих відділень і факультетів, Тернопіль 1999. 
діння мовою як іноземною, лексичний мінімум, початковий етап навчання української мови як іноземної, комплексне навчання видів мовленнєвої діяльнос$m i$ тощо. Крім практичного спрямування, що полягає у створенні навчальних посібників, упродовж цього періоду було започатковано теоретичний напрям, пов'язаний із описом різноаспектних питань методики викладання УМI. Наукові праці містять тлумачення базових термінооодиниць методичної науки, окреслюють основні поняттєві аспекти та мовні засоби для їх вираження.

Окремі теоретичні аспекти методики викладання УМІ науковці аналізують й у докторських дисертаціях. У дослідженні „Теоретичні основи використання засобів масової інформації у навчанні української мови студентів-нефілологів” Г. Онкович ${ }^{11}$ зокрема акцентує увагу на проблемах, що з'являються у процесі вивчення української мови іноземними студентами нефілологічного профілю.

Грунтовно дослідила проблеми викладання української мови як іноземної й Л. Паламар. Вона окреслила „першочергові завдання дисципліни Українська мова як іноземна: 1) опис української мови для іноземців з урахуванням: а) особливостей мови студентів; б) комунікативного мінімуму для різних контингентів, що вивчають мову, із залученням психологічних і соціолінгвістичних досліджень; в) лінгвокраїнознавчого й країнознавчого мінімуму, необхідного для спілкування в побутовій і соціокультурній сферах; 2) вивчення сучасних методів навчання: інтенсивних, комунікативних, аудіовізуальних тощо"12 Виокремивши такі основні положення, Л. Паламар визначила поняттєву базу, що трансформується із розвитком методики викладання УМІ як науки. Крім того, названа дослідниця окреслила зміст базових термінів: методика викладання украӥнської мови як іноземної та методика викладання украӥнської мови як спорідненої.

Вагомий внесок у розвиток методики викладання УМI, зокрема такого iii аспекту, як базової методичної підготовки викладачів української мови як іноземної, здійснила А. Бронська. Досліджуючи вищезазначене питання ${ }^{13}$, науковець запропонувала тлумачення багатьох методичних терміноодиниць, а також уклала термінологічний мінімум із методики викладання української мови як іноземної, що містить 643 одиниці.

Протягом 1996-1997 рр. створено Програму практичного курсу украӥнської мови для іноземних студентів та стажистів ${ }^{14}$ і Програму викладання курсу сучасної украӥнської літературної мови в умовах діаспори та як іноземної $^{15}$. Програми містять базові методичні терміноодиниці, що стосуються організації навчального процесу: базовий курс, основний курс, комунікативно спрямоване навчання та ін.

\footnotetext{
${ }^{11}$ Г. Онкович, Зазнач. праия.

${ }^{12}$ А. А. Бронська, Теоретичні основи базової методичної підготовки викладачів української та російської мов як іноземних, Київ 2002, с. 15.

${ }_{13}$ А. Бронська, Методична компетениія викладача як об'єкт тестування, [в:] „Дивослово”, 2000, № 3; А. А. Бронська, Теоретичні основи базової методичної підготовки викладачів украӥнської та російської мов як іноземних, Київ 2002; А.А. Бронська, Формування базової комунікативної компетенції викладача української або російської мов як іноземних, [в:] Система і структура східнослов'янських мов, Київ 1999; А. Бронська, Формування методичної компетенції викладача української мови як іноземної (викладання граматики), [в:] „Іноземні мови”, Київ 1997, № 4.

${ }^{14}$ Програма практичного курсу української мови. Для іноземних студентів та стажистів. Усне мовлення, упоряд. Н. К. Присяжнюк, А. В. Максименко, Київ 1997.

${ }^{15}$ Програми викладання курсу сучасної украӥнської літературної мови в умовах діаспори mа як іноземної, розроб. О. Лещак та ін., [в:] „Лабораторія славістичних студій”, серія україністики, Тернопіль 1996, вип. 4.
} 
Отже, протягом 90-х рр. XX ст. відбулися повільні, але знакові для розвитку методики викладання української мови як іноземної зміни.

Процес впливу науково-методичних праць $з$ української мови для іноземців на виформовування термінології $є$ двостороннім. Якщо спершу існувала закономірність, що наукова інформація впливає на становлення терміносистеми науки, то наступним етапом стане зворотний процес - уніфіковані методичні терміни сприятимуть точності фахової мови методики викладання УМІ, а отже, більшій науковості практики творення як підручників з української мови як іноземної, так і інших наукових праць.

Актуальним завданням залишається створення спеціального комплексного методичного посібника з методики викладання української мови як іноземної, що узагальнюватиме всі основоположні принципи системи навчання української мови як іноземної і стане орієнтиром для всіх фахівців цієї сфери. 